\author{
ks. Wojciech Zyzak ${ }^{1}$ \\ Uniwersytet Papieski Jana Pawła II w Krakowie
}

\title{
Miłosierdzie jako termin teologiczny
}

Jedną z charakterystycznych cech katolickiej myśli teologicznej podczas pontyfikatu błogosławionego Jana Pawła II było ożywienie zainteresowania tematem miłosierdzia w związku z papieskim nauczaniem, zwłaszcza z encykliką Dives in misericordia i popularyzacją kultu Bożego miłosierdzia w formie przekazanej świętej siostrze Faustynie Kowalskiej. Obfita literatura na ten temat dotyczy bardziej kwestii miłosierdzia Bożego niż miłosierdzia ludzkiego ${ }^{2}$. Już sam podział tej tematyki uświadamia, że miłosierdzie jako termin teologiczny jest rozpatrywane wieloaspektowo. Nie jest to pojęcie jedynie chrześcijańskie, dlatego wymaga sięgnięcia przynajmniej do tych starożytnych myślicieli pogańskich, którzy mieli wpływ na teologów katolickich. Zasadniczo jednak chrześcijańskie miłosierdzie czerpie ze źródła Pisma Świętego, dlatego nie można w jego prezentacji pominąć aspektu biblijnego. Już Pismo Święte, odsłaniając Boże miłosierdzie, co jest szczególnie przedmiotem zainteresowania dogma-

$1 \quad$ Ks. prof. dr hab. Wojciech Zyzak, ur. 17 czerwca 1969 w Żywcu, kapłan diecezji bielsko-żywieckiej, święcenia 15 maja 1993 roku, doktorat KUL 2000, habilitacja PAT 2006, profesura tytularna UPJP2 2013. Rektor Uniwersytetu Papieskiego Jana Pawła II w Krakowie. Autor 9 książek i ponad 80 artykułów. Ostatnie publikacje książkowe: Co mam czynić, aby osiagnaçć życie wieczne? Duchowość chrześcijańska na świeckiej drodze życia, Kraków 2007; Kapłaństwo prezbiterów. Studium nauczania Jana Pawła II, Kraków 2010. 2006, s. 11. 
tyki, wzywa do miłosierdzia względem człowieka, czym zajmuje się teologia moralna, a w wymiarze zespołowym katolicka nauka społeczna. Miłosierdzie jest też ważnym tematem teologii duchowości, pastoralnej, liturgiki i prawa kościelnego. Pewne aspekty miłosierdzia jako problemu teologicznego odsłania sztuka chrześcijańska, a nawet psychologia. Każda z tych dziedzin patrzy na miłosierdzie w swój własny, ale przecież ostatecznie komplementarny sposób. W krótkim artykule nie jest możliwe ukazanie wszystkich szczegółowych aspektów miłosierdzia w omawianych dyscyplinach. Dlatego poniżej zostaną jedynie zasygnalizowane główne kierunki rozwoju tego terminu.

\section{Miłosierdzie w ujęciu starożytnych filozofów pogańskich}

Termin „miłosierdzie” w kulturze grecko-rzymskiej występuje w różnych kontekstach. Stosowane tu łacińskie i greckie słowa mają dla teologii pewne znaczenie, gdyż w pierwszych wiekach Kościoła zostały w dużym stopniu przejęte przez chrześcijańskich pisarzy. Łacińska misericordia oznaczała współczucie i litość oraz uczynki miłosierdzia. Głównym źródłem tego słowa jest złożenie miser (nieszczęśliwy, ubogi) i cor (serce). W kulturze greckiej bliskie temu znaczenie miało słowo ع̂̉ jące miłosierdzie, współczucie i litość. Od niego pochodzi jałmużna (eleemosyne). Używano też terminów oiktirmos i splanchna, które odnajdziemy również w Piśmie Świętym. Bliska znaczeniowo słowu eleos była filantropia, jako dobrotliwość, życzliwość, łagodność i uprzejmość. W łacinie pokrewne terminy oznaczające łaskawość wobec czyjegoś nieszczęścia to humanitas i clementia. Z tym wiązała się szczodrobliwość (liberalitas, beneficium, benignitas).

Jeśli chodzi o samą rzeczywistość miłosierdzia, to można zauważyć u starożytnych ewolucję jego ujmowania: od bardzo pozytywnego u Homera do traktowania go jako wady przez Arystotelesa i stoików. Akceptowano miłosierdzie jako współczucie wobec ludzkiego cierpienia, zwłaszcza w sytuacji bez wyjścia, na przykład w śmiertelnej chorobie. Jednak już Platon twierdził, że sędzia nie powinien kierować się miłosierdziem. Jeszcze bardziej sceptycznie oceniał je Arystoteles, dla którego miłosierdzie było 
reakcją emocjonalną, więc niedojrzałą. Stanowiło nie cnotę, lecz wadę, wybaczaną jedynie starcom, kobietom i dzieciom. Jego zdaniem człowiek dojrzały winien się kierować rozumem i panować nad wszystkimi emocjonalnymi odruchami natury. Z takim ujęciem miłosierdzia polemizował później św. Tomasz z Akwinu, dla którego stanowiło ono cnotę. Tymczasem stoicy uważali miłosierne współczucie nawet za rodzaj choroby duszy (aegritudo animi). Cyceron twierdził, że misericordia jest raczej wadą niż cnotą, gdyż rodzi cierpienie. Należało ją okazywać tylko cierpiącym niesłusznie i pokrzywdzonym przez prawo. Czasami jednak chwalił miłosierdzie jako cnotę godną najwyższego podziwu (Pro Ligario) oraz oznakę mądrości i moralności (Pro Murena). Podobnie Seneka uważał, że misericordia jako stan emocjonalny zakłóca równowagę umysłu i przeszkadza w prawidłowym decydowaniu o słusznej karze tych, którzy zawinili. Uznał ją za wadę cechującą ludzi nikczemnych. Jednak i u niego można znaleźć pozytywne wypowiedzi na jej temat (De beneficiis). Trzeba dodać, że Cyceron i Seneka uważali miłosierdzie za wadę jako filozofowie, natomiast jako politycy w życiu praktycznym doceniali jego rolę i widzieli potrzebę stosowania w konkretnych wypadkach ${ }^{3}$.

\section{Miłosierdzie w Piśmie Świętym Starego i Nowego Testamentu}

Oczywiste jest, że dla teologów zastanawiających się nad miłosierdziem pogańscy filozofowie ze swymi terminami nie mieli tak wielkiego znaczenia jak Pismo Święte. W Starym i Nowym Testamencie Bóg objawił się jako Bóg miłosierdzia. Jahwe w słowach i czynach daje się poznać narodowi wybranemu jako miłosierny, głównie przez dwa podstawowe doświadczenia: opieki i przebaczenia. Przekonanie o miłosierdziu Boga stanowi podstawowe doświadczenia całej historii narodu wybranego ${ }^{4}$. Już w tym ujęciu nie było sprzeczności między miłosierdziem a sprawiedliwością, S. $67-71$.

3 Por. J. Zabielski, Wydobywanie dobra. Teologia chrześcijańskiego miłosierdzia, dz. cyt.,

4 Por. J. Zabielski, Wydobywanie dobra. Teologia chrześcijańskiego miłosierdzia, dz. cyt., s. 52 n. 
gdyż dla Izraelity usprawiedliwiająca sprawiedliwość Boga była miłosierną wiernością woli zbawienia. Jego kara była oczyszczeniem, a nie zemstą Jeśli chodzi o słownictwo, to hebrajski i grecki na określenie miłosierdzia używali kilku terminów. Najczęściej były to rdzenie słowne דחט (hesed - dobro), רחם (raham - zmiłować się) i חנך (hanan - być łaskawym), oraz

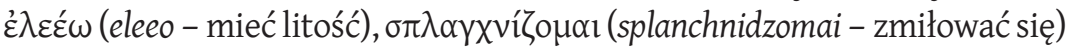

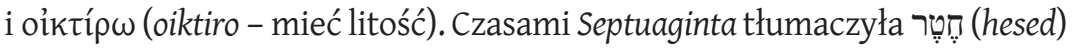

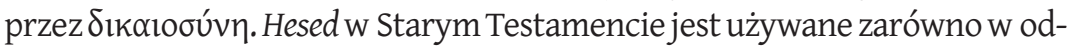
niesieniu do Boga, jak i w kontekście relacji międzyludzkich. Może oznaczać pojedynczy czyn i trwałą postawę. W odniesieniu do człowieka ma charakter wzajemności, która w wypadku Boga oznacza przekazywanie dalej doświadczonej od Niego dobroci. Bóg wielokrotnie okazywał hesed w odniesieniu do jednostek, narodu wybranego i całej ludzkości: „Bóg miłosierny i łagodny, nieskory do gniewu, bogaty w łaskę i wierność” (Wj 34, 6n). Kolejny rdzeń רחם (raham) oznacza uczucie współczucia oraz płynące z niego okazywanie pełnej miłości i przychylności. Najczęściej Bóg jest podmiotem takiego zmiłowania (Iz 55, 7; Oz 14, 4). חנך (hanan) podobnie jak hesed oznacza dobry czyn oraz postawę i głównie odnosi się do Boga. Wyraża wolny dar bez oczekiwania wzajemności.

Komentatorzy najczęściej porównują hesed z raham, a w zasadzie z formą rahamim. Hesed występuje pierwotnie w relacjach międzyludzkich. Oznacza dobroć, życzliwość i wierność na zasadzie wewnętrznego zobowiązania, przy czym nie chodzi tu przede wszystkim o uczucie czy wewnętrzne usposobienie, ale o czynną pomoc. Hesed podkreśla wierność sobie samemu i odpowiedzialność za własną miłość, co stanowi jakby bardziej męskie cechy. Wtórnie użyte w stosunku do Boga wyraża łaskę wierności Przymierzu. Z kolei rahamim wskazuje na miłość bardziej matczyną, skoro stanowi liczbę mnogą od słowa „łono”. Z największej pierwotnej bliskości, jaka łączy matkę z dzieckiem, wynika szczególny charakter relacji darmowej miłości. Chodzi tu o postawę naznaczoną emocjonalnością, czułością, tkliwością i wyrozumiałością. Tak więc w Starym Testamencie

Por. C. G. Andrade, Boskie atrybuty w świetle nauki o Trójcy Świętej, tłum. G. Ostrowski, [w:] Bóg bogaty w miłosierdzie, red. L. Balter, S. Dusza, A. Piętka, Poznań 2003, s. 41 (Kolekcja Communio, 15). 
Bóg jest podmiotem miłosierdzia, które jest owocem przymierza, ale może charakteryzować się elementami uczuciowymi. Otrzymane od Boga miłosierdzie zobowiązuje do okazywania go innym ${ }^{6}$. Można więc powiedzieć, że księgi Starego Testamentu rysują jasny i właściwie pełny obraz miłosierdzia. Ukazują je w Bogu i człowieku, wskazują na jego istotę i różne przejawy, zarówno w życiu jednostek, jak i narodu wybranego. Jednak potrzeba było jeszcze czegoś zupełnie nowego, czyli przykładu i ofiary wcielonego Miłosierdzia, żeby starotestamenowa postawa otrzymała swój najgłębszy sens ${ }^{7}$.

W Nowym Testamencie najczęściej stosowaną grupą semantyczną

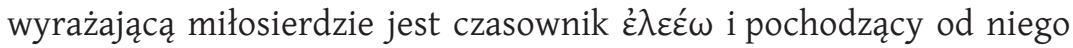

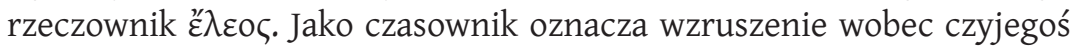
nieszczęścia i płynący z niego czyn pomocy. Jako rzeczownik oznacza miłosierdzie i odpowiada najczęściej hebrajskiemu rdzeniowi hesed. W Nowym Testamencie dotyczy przede wszystkim człowieka i Boga, który się do niego zniża, by mu pomóc, uleczyć go i przebaczyć winy. W relacjach międzyludzkich oznacza miłosierdzie, współczucie, przebaczenie i życzliwość. W pismach Pawłowych i Deuteropawłowych na pierwszy plan wysuwa się całkowicie wolne miłosierdzie Boga (Rz 9, 15-18). Zbawienie Żydów i pogan jest wynikiem Bożego miłosierdzia (Rz 11, 30n; 15, 9). $\mathrm{W}$ wielu miejscach sens miłosierdzia jest bliski łasce Bożej. Tymczasem w ewangeliach synoptycznych pierwszoplanowe jest żądanie przez Boga miłosierdzia od człowieka. W Mt 5, 7 Bóg obiecuje miłosiernym miłosierdzie. U świętego Jana termin ten nie występuje.

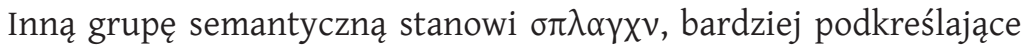
uczucia wzruszenia i litości, zapewne przez związek z wnętrznościami

${ }_{6}$ Por. J. Zabielski, Wydobywanie dobra..., dz. cyt., s. 20n., 60n; W. Słomka, Miłosierdzie Boże, [w:] Leksykon duchowości katolickiej, pod red. M. Chmielewskiego, Lublin-Kraków 2002, s. 522; I. Broer, Barmherzigkeit. I. Biblisch, [w:] Lexikon für Theologie und Kirche, t. II, Freiburg i. Br. 2006, k. 13n; J. Upton, Mercy, [w:] The new dictionary of Catholic spirituality, Collegeville 1993, s. 653n; J. Machniak, Doświadczenie Boga w tajemnicy Jego miłosierdzia u bł. Siostry Faustyny Kowalskiej, Kraków 1998, s. 15; R. Ukleja, Miłosierdzie Boże z pokolenia na pokolenie, Wrocław 1997, s. 18n. Szerzej na ten temat pisze S. Hałas, Biblijne słownictwo miłości i miłosierdzia na zderzeniu kultur, Kraków 2011.

Por. J. Homerski, Miłosierdzie w księgach Starego Testamentu, [w:] Miłosierdzie w postawie ludzkiej, red. W. Słomka, Lublin 1989, s. 26 (Homo Meditans, 5). 
(splanchna). Czasownik używany tylko przez synoptyków zawiera także moment czynu. Kolejna grupa oik $\tau i ́ p \omega$ (oiktiro) nawiązuje do rahamim i wyrażając czułość, wzruszenie i serdeczne współczucie, najczęściej odnosi się do Boga. W Nowym Testamencie miłosierdzie jest ujmowane przez pryzmat osoby i dzieła Jezusa Chrystusa, zwłaszcza Jego Misterium Paschalnego. Prawda o miłosierdziu Boga jest wiodącą treścią głoszonej przez Chrystusa nauki i zasadniczym motywem Jego dzieła zbawienia. Uprzedzające Boże miłosierdzie tłumaczy wymaganie miłosierdzia stawiane człowiekowi. Bóg bogaty w miłosierdzie dał wszystkim ludziom udział w paschalnej tajemnicy Chrystusa, udostępniając dowody swego miłosierdzia w Kościele przez pośrednictwo Matki Miłosierdzia ${ }^{8}$.

\section{Dogmatyczno-systematyczne podstawy miłosierdzia}

$\mathrm{Na}$ fundamencie biblijnym rozważania na temat miłosierdzia Bożego prowadzi przede wszystkim dogmatyka katolicka. Tu miłosierdzie jest rozpatrywane jako niczym niezasłużone i wolne zwrócenie się Boga ku stworzeniu, czyli nie tyle przymiot istoty Boga, ile pokrewny z łaską, ujmowany z historiozbawczej perspektywy wyraz Jego istotowej miłości. Bóg manifestuje swe miłosierdzie, zwracając się swą bliskością ku cierpiącym i swą przebaczającą przychylnością ku grzesznikom. Przez to miłosierdzie pozostaje w relacji pewnego napięcia do sprawiedliwości. Jeśli sprawiedliwość oddaje każdemu, co mu się należy, to oczywiste jest, że takie oddanie ze strony Boga zawsze jest niezasłużone i płynie z miłosierdzia, które jest miarą sprawiedliwości. Niektórzy teologowie bardziej polaryzują miłosierdzie i sprawiedliwość. W ujęciu Anzelma z Canterbury, ale także współcześnie w myśli Karola Bartha sprawiedliwość niemal z konieczności zmierza ku potępieniu grzesznika. Tylko ten, kto zmierza jej drogą aż do tej ostateczności, zrozumie nadmiar miłosierdzia Boga, któ-

\footnotetext{
8 Por. I. Broer, Barmherzigkeit. I. Biblisch..., dz. cyt., k. 14n; J. Zabielski, Wydobywanie dobra..., dz. cyt., s. 53, 63n.
} 
ry sam w Chrystusie wziął na siebie niewolę i potępienie człowieka, by udzielić przebaczenia i przywrócić wolność grzesznikowi ${ }^{9}$.

Miłosierdzie jako główny motyw Bożego działania było przedmiotem rozważań ojców Kościoła (Augustyna, Jana Chryzostoma, Piotra Chryzologa) i teologów średniowiecznych (Bernarda z Clairvaux i Tomasza z Akwinu) ${ }^{10}$. Scholastyka tradycyjnie odróżniała przymioty „wsobne”, należące do Boga jako bytu samego w sobie (niezłożoność, nieskończoność, wieczność, niezmienność), od „odnośnych”, które ujawniają się w Bożych dziełach wobec stworzeń (mądrość, dobrotliwość, opatrzność, sprawiedliwość, miłosierdzie). Przez analogię do duchowych władz człowieka mówiono, że przymioty mądrości i opatrzności mają swoje miejsce w umyśle Boga, zaś dobrotliwość, sprawiedliwość i miłosierdzie związane są z Jego wolą. Miłosierdzie jest tu ujmowane jako udzielanie przez Boga dobra człowiekowi, by go wyprowadzić ze słabości i braków ${ }^{11}$. Nie naruszając Bożej niezmienności, zakłada jakąś formę współczucia. Tradycja teologiczna mówi o miłosierdziu Bożym jako nieskończonym, gdyż będącym przymiotem nieskończonej natury Boga i owocem Jego nieskończonej miłości. Jest ono głównym motywem działania Bożego na zewnątrz ${ }^{12}$. Tak więc miłosierdzie Boga jest przymiotem, a nie tylko stanem współczującego umysłu ${ }^{13}$.

Co więcej, w objawieniach św. Faustyny Kowalskiej miłosierdzie jest określone jako „największy przymiot Boga” ${ }^{14}$. Oczywiście miłosierdzie jako doskonałość Boga, w którym wszystkie przymioty stanowią Jego istotę, jest równe sprawiedliwości, mądrości, dobrotliwości i opatrzności. Jednak jako przymiot charakteryzujący działanie Boga jest największe, gdyż polega na udzielaniu się bytu najwyższego bytom niższym. Miłosierdzie jest największą doskonałością w bycie najwyższym, niemającym nad sobą bytu, któremu mógłby się poddać przez miłość. Jest to jasne w wypadku porównania z człowiekiem, którego istotę doskonałości i najwyższą cnotę stanowi

\footnotetext{
9 Por. E. Salmann, Barmherzigkeit. II. Systematisch-theologisch, [w:] Lexikon für Theologie und Kirche, t. II, Freiburg i. Br. 2006, k. 15.

10 Por. M. J. Scheeben, Handbuch der Katholischen Dogmatik, t. IV, Freiburg 1948, s. 264-271.

11 Por. J. Machniak, Doświadczenie Boga..., dz. cyt., s. 16.

12 Por. J. Machniak, Doświadczenie Boga..., dz. cyt., s. 17n.

13 Por. Tomasz z Akwinu, Summa theologica, I, q. 21, a. 3.

14 Por. W. Słomka, Miłosierdzie Boże..., dz. cyt., s. 523.
} 
miłość, łącząca z bytem najwyższym ${ }^{15}$. W tym sensie również sprawiedliwość podporząadkowuje się miłosierdziu, bowiem cokolwiek Bóg czyni dla stworzeń, czyni według należnego porządku, który stanowi sprawiedliwość. Ale ponieważ ten porządek został przyjęty przez Boga zupełnie dobrowolnie, dlatego w jego ustanowieniu trzeba również widzieć nieskończone Boże miłosierdzie, które przewyższa sprawiedliwość ${ }^{16}$.

Rozważanie na temat Bożego miłosierdzia w wymiarze trynitarnym nabiera charakteru chrystologicznego przez fakt, że najpełniejszym jego objawieniem jest tajemnica wcielenia, która osiąga swój szczyt w śmierci i zmartwychwstaniu Chrystusa ${ }^{17}$. Tu jest też podstawa do eklezjologicznej refleksji nad Bożym miłosierdziem, skoro Kościół, będący owocem Tajemnicy Paschalnej nie tylko je głosi i wyznaje, nie tylko stara się je przywoływać i naśladować, ale także je urzeczywistnia i uobecnia jako sakrament zbawienia, czyli okazywanego wciąż światu Bożego miłosierdzia ${ }^{18}$. Refleksja eklezjologiczna musi znaleźć swą kontynuację w refleksji sakramentologicznej. Analizując najgłębszą naturę sakramentu, czyli wydarzenia Chrystusa uobecnianego w liturgii, dochodzi się do tajemnicy Ojca miłosierdzia ${ }^{19}$. Dotyczy to szczególnie Chrztu, Eucharystii i sakramentu pojednania, w którym dokonuje się spotkanie z Chrystusem miłosiernym i przebaczającym grzechy ${ }^{20}$. Właśnie w przebaczeniu najbardziej objawia się miłosierna miłość Boga do człowieka. Miłosierdzie wyrażające się w odpuszczeniu grzechów jest też najbardziej oczywistym dowodem Bożej wszechmocy ${ }^{21}$.

15 Por. Tomasz z Akwinu, Summa theologica, II-II, q. 30, a. 4, c; J. Machniak, Doświadczenie Boga..., dz. cyt., s. 19.

16 Por. Tomasz z Akwinu, Summa theologica, I, q. 21, a. 4, c; J. Machniak, Doświadczenie Boga..., dz. cyt., s. 19n.

17 Por. A. Słomkowski, Miłosierdzie Boże we Wcieleniu i Odkupieniu, [w:] Ewangelia Miłosierdzia, red. W. Granat, Poznań 1970, s. 49-112.

18 Por. L. Balter SAC, Kościół jako sakrament Bożego Miłosierdzia, [w:] Bóg bogaty w miłosierdzie, dz. cyt., s. 173.

19 Por. N. Bux, Miłosierne działanie Trójcy Świętej w sakramentach, przeł. L. Balter, [w:] Bóg bogaty w miłosierdzie, dz. cyt., s. 196.

20 Por. S. Mojek, Miłosierdzie Boże w sprawowaniu sakramentu pojednania, [w:] Miłosierdzie w postawie ludzkiej, dz. cyt., s. 130-134.

${ }_{21}$ Por. Tomasz z Akwinu, Summa theologica, I, q. 25, a. 3, ad 3; J. Machniak, Doświadczenie Boga..., dz. cyt. s. 20n. 
Dogmatyczna refleksja nad Bożym miłosierdziem niezmiennie przeradza się w gorącą dyskusję w kontekście eschatologii. Współcześnie eschatologia, która podkreśla rolę miłosierdzia Bożego, jest całkowicie odmienna od wizji odpłaty i wyrównania, które dominowały w ujęciu tradycyjnym. Podkreślenie miłosierdzia Bożego w kwestiach eschatologicznych pozwala człowiekowi spoglądać z nadzieją w przyszłość. Nadzieja na spotkanie z Bogiem sprawiedliwym i miłosiernym powinna dynamizować całe ziemskie życie. Chociaż najwłaściwszą kategorią mówienia o prawdach ostatecznych jest nadzieja, nie powinno to zwalniać człowieka od odpowiedzialności za jego postępowanie ${ }^{22}$. Troska o to towarzyszy dyskusji nad kwestią nadziei zbawienia dla wszystkich. W ujęciu Wacława Hryniewicza argumenty za taką nadzieją zdają się w rzeczywistości iść dalej, zaprzeczając możliwości potępienia kogokolwiek. Wieczne cierpienie Boga musiałoby w konsekwencji łączyć się także z cierpieniem zbawionych, którzy zjednoczeni z Nim, odczuwaliby podobnie jak On dramat zatracania się człowieka ${ }^{23}$.

\section{Etyczno-moralne aspekty miłosierdzia}

Teologia moralna interesuje się miłosierdziem głównie w aspekcie relacji międzyludzkich. Tu miłosierdzie jest formą miłości, która spontanicznie zwraca się ku drugiemu, znajdującemu się w potrzebie pomocy. Człowiek miłosierny cierpi i solidaryzuje się z bliźnim oraz stara się oddalić wszystko, co uniemoźliwia jego rozwój. Wzór takiej postawy ukazał Chrystus w przypowieści o miłosiernym Samarytaninie (Łk 10, 33n), który zauważył, współczuł i podjął konkretne działanie, by pomóc pokrzywdzonemu. W myśli ojców Kościoła miłosierdzie zajmowało centralne miejsce nie tylko ze względu na obowiązek czynienia dobrze bliźnim, lecz także ze względu na jego obiektywną wartość, skutki w działającym

22 Por. G. Kucza, Ostateczne wydarzenia człowieka a Boże Miłosierdzie, [w:] Bóg bogaty w mitosierdzie, dz. cyt., s. 355n.

${ }^{23}$ Por. S. Drzyżdżyk, S. Haberka, Nadzieja czy apokatastaza? Refleksje nad eschatologia Wacława Hryniewicza, „Polonia Sacra” 14 (32) 201026 (70), s. 142. 
i znaczenie dla wspólnoty. Św. Tomasz z Akwinu przyznał miłosierdziu status cnoty moralnej. Choć jej przedmiotem są uczucia, pochodzi ona ze sprawności intelektualno-wolitywnej i jest bliska miłości, posiadając odmienną pobudkę w postaci nędzy człowieka. Wyeksponowanie elementu współczucia w scholastyce doprowadziło do oddzielenia miłosierdzia od miłości, jak i od jej dzieł. W tym ujęciu nie widzi się dzieł miłosierdzia jako działania Kościoła i nie docenia się ich społecznego znaczenia. Nacisk na uczynki miłosierdzia zaciemnił interpretację miłosierdzia jako cnoty. W koncepcji aktualistycznej sama istota miłosierdzia została zacieśniona przez utożsamienie z uczynkiem, aktem, eksponując czyn dobro-czyńcy, a pomijając znaczenie czynu i dobro-biorcy. Krytycy tego ujęcia podkreślają, że ostateczną racją miłosierdzia nie są niedole, lecz naśladowanie miłosierdzia Boga oraz godność osoby ludzkiej. W konsekwencji w potrydenckiej teologii zredukowano miłosierdzie do jałmużny. Oczywiście praktyka uczynków miłosierdzia ma olbrzymie, nie tyle teologiczne, ile życiowe znaczenie. Zgodnie z Ewangelią (Mt 25, 31-46) będą one stanowić kryterium sądu Bożego. Tradycja wypracowała po siedem uczynków względem ciała i duszy ${ }^{24}$.

Miłosierdzie należy traktować jako powołanie, nakładające rzeczywisty obowiązek. W religijno-moralnym życiu i posłannictwie chrześcijanina miłosierna miłość stanowi normę postępowania. Wolą Chrystusa jest, by człowiek nie tylko doświadczał Bożego miłosierdzia, ale czynił je również drugiemu ${ }^{25}$. Tak więc życie chrześcijanina realizowane jest w oparciu o moralną normę miłości Boga i bliźniego, której szczególną formą jest miłość miłosierna, czyli miłosierdzie ${ }^{26}$. Trzeba jednak podkreślić, że miłość nie może być zastąpiona przez miłosierdzie, gdyż między Bogiem o człowiekiem nie ma w tym wymiarze wzajemności i odpowiedzią na Jego miłosierdzie jest miłość. Miłosierdzie jest więc jakby częścią (pars) miłości

${ }^{24}$ Por. Tomasz z Akwinu, Summa theologica, II-II , q. 30, a. 3; J. Zabielski, Wydobywanie dobra..., dz. cyt., s. 80, 83n; A. Elsässer, Barmherzigkeit. III. Theologisch-ethisch, [w:] Lexikon für Theologie und Kirche, t. II, Freiburg i. Br. 2006, k. 15n; B. Ferdek, Miłosierdzie, [w:] Leksykon duchowości katolickiej, dz. cyt., s. 518n.

25 Por. F. Greniuk, Czynić miłosierdzie drugim, [w:] Miłosierdzie w postawie ludzkiej, dz. cyt., s. 59; J. Zabielski, Wydobywanie dobra..., dz. cyt., s. 109.

${ }^{26}$ Por. J. Zabielski, Wydobywanie dobra..., dz. cyt., s. 177. 
ze względu na kondycję uwikłanych w zło stworzeń. Jest to część miłości, gdyż nie wszystko stworzenie jest aktualnie osaczone przez zło ${ }^{27}$. Niemniej jednak współczesną interpretację miłosierdzia charakteryzuje pogłębienie personalistycznego wymiaru relacji miłosierdzia do miłości, głównie pod wpływem encykliki Dives in misericordia Jana Pawła II. Poprzednio odróżniano miłosierdzie od miłości, zaś obecnie dokonuje się integracji, a nawet identyfikacji tych dwóch rzeczywistości. Miłosierdzie to wewnętrzny kształt, nieodzowny wymiar, sposób objawienia i realizowania się miłości. Motywem i egzystencjalnym uzasadnieniem tak pojmowanej miłosiernej miłości jest bliźni znajdujący się w trudnej sytuacji. To wymaga etosu miłosierdzia, czyli bycia miłosiernym w całym życiu. Personalizm natury miłosierdzia wypływa z głębi tajemnicy jego objawienia, jaką jest Jezus Chrystus. Tu nie chodzi jedynie o pojęcie, ale o kategorię na wskroś osobową. Chrystus bowiem, objawiając miłosierdzie, nie tylko mówi o nim, ale nade wszystko sam je uosabia ${ }^{28}$.

Miłosierdzie jako akt miłości miłosiernej polega na wspólnym przeżyciu dobra, jakim jest osoba, oraz na wspólnym doświadczeniu jej godności. Atrybutami tak rozumianego miłosierdzia są: współuczestnictwo w dobru osoby, wzajemność doświadczenia tego dobra, zrównanie osób przy zachowaniu ich ontycznej odrębności oraz wierność osobie. W pełnym i właściwym kształcie miłosierdzie urzeczywistnia się w odniesieniu Boga do człowieka, jednak w sposób analogiczny realizuje się w relacjach między ludźmi, którzy naśladują Boga „bogatego w miłosierdzie”29. Współuczestnictwo w dobru osoby i jej godności, stanowiące zasadniczy atrybut chrześcijańskiej idei miłosierdzia, jest możliwe wtedy, gdy cechuje się wzajemnością. Stąd też miłosierna miłość we wszystkich relacjach międzyludzkich zawsze jest procesem obustronnym. Wzajemność doświadczanego w miłosierdziu dobra stanowi podstawę równości i solidarności międzyludzkiej oraz jest drogą do autentycznej sprawiedliwości. Bez swoistego wyrównania, jakie wnosi miłosierdzie, walka o ścisłą sprawiedliwość może stać się nieludzka S. $57 n$.

27 Por. M. Bernaś, Miłosierdzie jako przymiot Boga, [w:] Bóg bogaty w miłosierdzie, dz. cyt.,

28 Por. J. Zabielski, Wydobywanie dobra..., dz. cyt., s. 88n, 178.

29 Por. J. Zabielski, Wydobywanie dobra..., dz. cyt., s. 105. 
(summum ius summa iniuria). Miłosierdzie jest źródłem i udoskonaleniem sprawiedliwości, bo jest jej szczytowym wypełnieniem ${ }^{30}$. Do konkretnych postaci miłosierdzia zaliczamy kształtowanie wyobraźni miłosierdzia oraz rzeczywiste bycie bliźnim, czyli postawę nawrócenia ku osobie i trwanie przy niej. Powyższe wymagania dotyczą w dużym stopniu ujęcia miłosierdzia w katolickiej nauce społecznej. Zanim zajmiemy się tą kwestią, trzeba dodać, że świadomość niemożności zaradzenia wszystkim ludzkim niedolom każe zwrócić się do Ojca miłosierdzia w ufnej modlitwie. To kieruje rozważania o miłosierdziu na pole duchowości ${ }^{31}$.

Na koniec tej części wywodu warto sobie uświadomić, że konsekwencją zanegowania miłości miłosiernej w postawie ludzkiej są zarówno nietzscheański immoralizm i egocentryzm, jak też marksistowska idea walki klas ${ }^{32}$. W ramach witalistyczno-biologicznej koncepcji życia niektórzy (Niccolo Machiavelli, Vilfredo Pareto, Thomas Hobbes, Friedrich Nietzsche) odrzucili miłosierdzie, widząc w nim słabość, a nawet przeszkodę w rozwoju człowieka. Dla Nietzschego moralność oparta na idei miłosierdzia jest moralnością ludzi słabych, którym brak poczucia własnej wartości i dostojeństwa. Miłosierdzie jest więc oznaką upadku człowieka, zahamowaniem woli walki, nienawiści, okrucieństwa i siły ${ }^{33}$.Zbrodnie nazistowskie pokazały, do czego ostatecznie prowadzi takie ujęcie miłosierdzia.

\section{Społeczny wymiar miłosierdzia}

Zaangażowanie chrześcijan w posługę miłosierdzia poza wymiarem indywidualnym często przyjmuje także postać działalności społecznej i instytucjonalnej, tym cenniejszej, że wykonywanej dobrowolnie i nie dla zysku. Jeśli to zaangażowanie jest podejmowane z motywów ewangelicznych, stanowi formę apostolstwa ${ }^{34}$. Kościół przez całą swoją historię na różne sposo-

30 Por. J. Zabielski, Wydobywanie dobra..., dz. cyt., 178n.

31 Por. J. Zabielski, Wydobywanie dobra..., dz. cyt., s. 180.

32 Por. S. Kowalczyk, Konsekwencja zanegowania miłości i miłosierdzia w postawie ludzkiej, [w:] Miłosierdzie w postawie ludzkiej, dz. cyt., s. 232-239.

33 Por. J. Zabielski, Wydobywanie dobra..., dz. cyt., s. 84n.

34 Por. J. Zabielski, Wydobywanie dobra..., dz. cyt., s. 171. 
by przejawiał miłosierdzie, od posługi diakonów i pomocy materialnej siostrzanym wspólnotom, przez charytatywną działalność zakonów, bractw i szpitali w średniowieczu, aż po współczesne formy organizacji Caritas ${ }^{35}$.

Jednak wraz z pojawieniem się w XIX wieku idei państwa opiekuńczego, gwarantującego bezpieczeństwo socjalne, zaczęło się wydawać, że miłosierdzie jako główna cnota społeczna straciło na znaczeniu. Odtąd miłosierdzie zaczęto kojarzyć z wyniosłością, fałszywą litością lub kamuflażem zaniedbanych reform strukturalnych. Zwłaszcza w marksizmie powtarzano, że ubodzy nie potrzebują pomocy charytatywnej, ale sprawiedliwości. Jest w tym coś z prawdy, choć trzeba dodać, że nawet tam, gdzie państwo zinstytucjonalizowało prawo do opieki socjalnej w szerokim zakresie, pozostaje wiele miejsca dla spontanicznej i ochoczej pomocy, której w wielu wypadkach nie da się niczym zastąpićs ${ }^{36}$. Do najważniejszych nieporozumień fałszujących wymiar miłosierdzia zaliczamy pozbawione społecznego odniesienia czysto indywidualistyczne lub jedynie duchowe jego rozumienie oraz panujące w zamożnych krajach przekonanie, że uczynki miłosierdzia straciły na znaczeniu, może poza pomocą krajom ubogim ${ }^{37}$.

Ambiwalencja wobec miłosierdzia przejawia się w postawie obojętności lub wrogości u jednych oraz dostrzeganiu w nim wielkiego wołania świata u innych. Odpowiedź na to wołanie winna przybrać różne postaci miłosiernej posługi, które już wcześniej zostały wymienione, czyli formę wyobraźni miłosierdzia, bycia bliźnim dla potrzebujących, usuwania nawarstwień zła, zawierzenia Bożemu miłosierdziu i głoszenia go światu. Są to inne postaci znanych w tradycji Kościoła uczynków miłosierdzia ${ }^{38}$. Wspomniany już ewangeliczny przykład miłosiernego Samarytanina nasuwa jako szczególnie przydatną w praktykowaniu miłosierdzia charakterystyczną dla katolickiej nauki społecznej metodę: widzieć, ocenić, działać3 ${ }^{39}$.

35 Por. B. Ferdek, Miłosierdzie..., dz. cyt., s. 519-522.

36 Por. Benedykt XVI, enc. Deus caritas est, 26; enc. Caritas in veritate, 6, 79; A. Elsässer, Barmherzigkeit. III. Theologisch-ethisch..., dz. cyt., k. 15n.

37 Por. J. Krucina, Komentarz do encykliki Jana Pawła II „Dives in misericordia”, [w:] Encyklika Ojca Świętego Jana Pawła II o Bożym Miłosierdziu „Dives in misericordia”, Wrocław 1996, s. 94.

${ }_{38}$ Por. J. Zabielski, Wydobywanie dobra..., dz. cyt., s. 167.

39 Kongregacja do Spraw Wychowania Katolickiego, Wskazania dotyczące studiów i nauczania doktryny społecznej kościoła w ramach formacji kapłańskiej, 1988, nr 7. 
W kulturze opartej na Bożym miłosierdziu chodzi przede wszystkim o obronę człowieka jako osoby obdarzonej niezbywalną godnością, rozumnej oraz wolnej, z natury społecznej, powołanej do miłości; podmiotu i uczestnika Bożych planów. Życie człowieka i ludzkości musi rozwijać się na fundamencie żywej, powszechnej kultury moralnej. Dlatego demokracja nie powinna przyjmować wyłącznie ekonomicznego modelu produktywności i konsumpcjonizmu, ale podjąć nowe, wspólne wysiłki na rzecz budowy społeczności ludzkiej, umiejącej dzielić się dobrami materialnymi i duchowymi ${ }^{40}$. Tu szczególnie ważne jest miłosierdzie, gdyż bez niego nie może być mowy o budowaniu i pogłębianiu cywilizacji miłości. Wobec ideologii nienawiści i walki klas chrześcijaństwo ukazuje prawdziwą równość i internacjonalizm wyrażony przez świętego Pawła w Liście do Galatów (3, 28). Dostrzegając grzeszność człowieka, wskazuje na tajemnicę miłosierdzia, z której płynie zobowiązanie, by w każdej sytuacji podać mu pomocną dłoń ${ }^{41}$.

\section{Miłosierdzie w duchowości chrześcijańskiej}

Miłosierdzie Boże wymaga przede wszystkim odpowiedzi w formie postawy całkowitego zaufania w akcie wiary, czyli zawierzenia ${ }^{42}$. Z analizy Dzienniczka świętej siostry Faustyny Kowalskiej wynika potrzeba poznania prawdy o Bożym miłosierdziu, zawierzenia Bożemu miłosierdziu, modlitwy o miłosierdzie i oddania czci Bogu w tej tajemnicy oraz kształtowania postaw i świadczenia czynów miłości miłosiernej. Duchowość chrześcijańska interesuje się wszystkimi tymi formami, ale w szczególny sposób bada przejawy pobożności i nabożeństwa do Bożego miłosierdzia ${ }^{43}$. Różne formy kultu Boga bogatego w miłosierdzie mają na celu uwielbienie Go i zbliżenie ludzi do Niego oraz otwarcie ich na działanie łaski, którą miłosierny Jezus pragnie każdego obdarzyć. Do podstawowych form kultu przekazanych

${ }^{40}$ Por. P. Warchoł OFMConv, Miłosierny Bóg i miłosierny człowiek. Teologiczna interpretacja miłosierdzia w nauczaniu Jana Pawła II, Wrocław 2007, s. 265n.

${ }_{41}$ Por. A. Nossol, Personalistyczno-humanistyczny aspekt $w$ doznawaniu i świadczeniu mitosierdzia, [w:] Miłosierdzie w postawie ludzkiej, dz. cyt., s. 51.

${ }^{42}$ Por. J. Machniak, Doświadczenie Boga..., dz. cyt., s. 21.

43 Por. W. Słomka, Miłosierdzie Boże..., dz. cyt., s. 523. 
przez św. Faustynę należą uczczenie obrazu Jezusa Miłosiernego, obchodzenie święta Bożego miłosierdzia oraz różne modlitwy do Bożego miłosierdzia, głównie koronka, nowenna i akty strzeliste, odmawiane szczególnie o godzinie piętnastej. Trzeba też dodać do tego duchową lekturę Dzienniczka, który może być cenną podstawą do medytacji ${ }^{44}$. Szczególną duchową więzią z tajemnicą Bożego miłosierdzia żyło wielu świętych, spośród których na podkreślenie zasługuje właśnie św. Faustyna Kowalska, „sekretarka” Bożego miłosierdzia. Wielu świętych zasłynęło też z postawy miłosierdzia, której szczególnym wzorem w naszej polskiej duchowości jest święty brat Albert Chmielowski ${ }^{45}$. Wynika z tego, że świętość, do której winna prowadzić prawdziwa duchowość, ma istotny związek z miłosierdziem. Dla duchowości chrześcijańskiej nie bez znaczenia jest również fakt, że wiele męskich i żeńskich wspólnot zakonnych odwołuje się w swej duchowości i nazwie do tajemnicy Bożego miłosierdzia ${ }^{46}$.

\section{Pastoralny wymiar miłosierdzia}

Wraz z rozwojem kultu Bożego miłosierdzia dostrzeżono potrzebę refleksji natury pastoralnej, starając się odpowiedzieć na pytanie, czy i dlaczego idea Bożego miłosierdzia może stanowić treść nowej ewangelizacji, a przez to przyczynić się do zaradzenia różnym zagrożeniom człowieka i ludzkości. Zauważono bowiem pewien związek przyczynowy pomiędzy pojawieniem się i rozkwitem kultu Bożego miłosierdzia w XX wieku a współczesnymi wyzwaniami Kościoła i świata. Idea miłosierdzia Bożego jest tu postrzegana jako środek zaradczy na zagrożenia istniejące w dzisiejszym świecie. Ukazanie różnorakich zagrożeń, ale i godności człowieka, a przede wszystkim Bożego miłosierdzia, ma inspirować do głoszenia tej prawdy bliźnim. Jest więc ta idea motywem do zaangażowania się

${ }^{44}$ Por. J. Machniak, Doświadczenie Boga..., dz. cyt., s. 279, 288.

45 Por. M. M. Wójtowicz, Miłosierdzie w postawie błogosławionego brata Alberta, [w:] Miłosierdzie w postawie ludzkiej, dz. cyt., s. 217n.

${ }_{46}$ Por. K. S. Frank, Barmherzigkeit. V. Ordensgenossenschaften, [w:] Lexikon für Theologie und Kirche, t. II, Freiburg i. Br. 2006, k. 16n; Barmherzige Brüder, Barmherzige Schwestern, [w:] Lexikon für Theologie und Kirche, t. II, Freiburg i. Br. 2006, k. 11-13. 
w dzieło ewangelizacji i do uczestnictwa w misji Kościoła. Skoro zasadniczą treść orędzia mesjańskiego Jezusa Chrystusa stanowi prawda o Bożym miłosierdziu, winna ona być inspirująca dla duszpasterstwa, szczególnie w wymiarze homiletycznym i katechetycznym ${ }^{47}$.

\section{Miłosierdzie w wymiarze liturgicznym}

Miłosierdzie Boże ma też wyraźny wymiar liturgiczny, gdyż, jak już wspomniano, sakramenty stanowią uprzywilejowane miejsce doświadczania i głoszenia miłosierdzia. Badania ksiąg liturgicznych, zwłaszcza Mszału rzymskiego, pokazują, jak wiele modlitw zawiera odniesienie do Bożego miłosierdzia ${ }^{48}$.Jeden z najstarszych aktów pokutnych w liturgii sięga do języka Pisma Świętego, by wołając „Kyrie eleison, Christe eleison”, prosić na początku mszy świętej o zmiłowanie Pańskie ${ }^{49}$. Również w centrum sakramentu pokuty sytuuje się pojednanie, którego źródłem jest bezwarunkowe miłosierdzie Boga. Dlatego Ordo paenitentiae z 1974 roku zaczyna się od słów: „Bóg Ojciec miłosierdzia”" Trzeba też przypomnieć, że miłosierdzie ma swoje czasy. Dniem miłosierdzia jest każda niedziela i wszystkie dni pokutne, ale szczególnie druga niedziela Wielkanocy ustanowiona dla Kościoła polskiego przez Jana Pawła II w 1995 roku Świętem Miłosierdzia Bożego, rozciągniętym następnie w 2000 roku na cały Kościół. Oprócz dni miłosierdzia liturgia Kościoła zna także godziny miłosierdzia, spośród których szczególne znaczenie ma godzina piętnasta jako godzina śmierci Chrystusa. Kościół przejął też z tradycji Starego Testamentu ideę jubileuszów, odniesionych do zbawczych wydarzeń Chrystusa i świętowanych szczególnie uroczyście w rytmie pięćdziesięciolecia, nawiązującym do roku miłosierdzia ${ }^{51}$.

${ }^{47}$ Por. W. Seremak SAC, Miłosierdzie Bożę a nowa ewangelizacja. Znaki czasu, Lublin 2001, S. 398 .

48 Por. J. Miazek, Bóg Miłosierdzia w modlitwach Mszału Rzymskiego, [w:] Miłosierdzie w postawie ludzkiej, dz. cyt., s. 113.

49 Por. Miłosierdzie, [w:] Religia. Encyklopedia PWN, red. T. Gadacz, B. Milerski, Warszawa 2003, s. 47.

50 Por. J. Servais, Spowiedź sakramentem Ojca Miłosierdzia. Profetyczna intuicja Adrienne von Speyr, [w:] Bóg bogaty w miłosierdzie, dz. cyt., s. 210.

51 Por. R. Forycki, Czasi czasy miłosierdzia, [w:] Bóg bogaty w miłosierdzie, dz. cyt., s. 332-335. 


\section{Miłosierdzie a prawo kościelne}

Wbrew pozorom idea miłosierdzia ma również swoje miejsce w prawie kościelnym. Miłosierdzie jest nawet kanonistyczną zasadą stosowania prawa, opartą o formuły aequitas canonica i salus animarum, zawarte w kanonach 19 i 1752 Kodeksu prawa kanonicznego. Ten ostatni kanon mówi, że zbawienie dusz winno być w Kościele najwyższym prawem. W tym duchu winno się rozwiązywać napięcie między sprawiedliwością i zasadniczą wiernością literze prawa a miłosierdziem i rozstrzyganiem konkretnych przypadków, które trafnie sformułował św. Tomasz z Akwinu: „iustitia sine misericordia crudelitas est; misericordia sine iustitia dissolutio". Niektórzy za wzór stawiają tutaj zasadę ekonomii (oikovouí $\alpha$ ), stosowaną w rozstrzygnięciach prawnych Kościoła prawosławnego ${ }^{52}$. Związek teologii miłosierdzia i prawa kościelnego uwidacznia się szczególnie tam, gdzie chodzi o przebaczenie, jak to ma miejsce na przykład w kanonach dotyczących sakramentu pokuty, kar kościelnych i odpustów ${ }^{53}$.

\section{Miłosierdzie w sztuce chrześcijańskiej}

Podobnie jak w liturgii zasada lex orandi lex credendi określa związek modlitwy z wiarą, tak również w sztuce chrześcijańskiej obecność i formy prezentacji miłosierdzia ukazują stan wiary danej epoki i miejsca. Przez wieki miłosierdzie było przedstawiane przede wszystkim w formie uczynków miłosierdzia. U Mateusza (25, 31-46) mamy sześć uczynków co do ciała. Podobno Laktancjusz w III wieku jako pierwszy dodał grzebanie umarłych. Od XII wieku znajdujemy sześć, a od XIII wieku siedem uczynków w ramach przedstawienia sądu ostatecznego w zdobieniach książek, elementach architektonicznych, witrażach i wyposażeniu świątyń (drzwi monasteru w Bazylei). Od XV wieku uczynki miłosierdzia występują w grafice i ma-

52 Por. T. Schüller, Barmherzigkeit. IV. Kirchenrechtich, [w:] Lexikon für Theologie und Kirche, t. II, Freiburg i. Br. 2006, k. 16.

53 Por. B. Fisichella, Odpust a Boże miłosierdzie, przeł. M. Tryc-Ostrowska, [w:] Bóg bogaty $w$ miłosierdzie, dz. cyt., s. 251n. 
larstwie sztalugowym (Bellini, Caravaggio, Murillo). W Polsce, w Muzeum Narodowym w Warszawie przykładem jest obraz Pietera Aertsena Czyny miłosierdzia chrześcijańskiego z 1575 roku. Czasami wizerunki świętych zastępują pomagających, a postać Chrystusa jest przedstawiona w miejsce potrzebujących. Takie motywy często dekorowały szpitale, a niekiedy ukazywały znanych świętych spełniających uczynki miłosierdzia (św. Elżbieta z Turyngii). Rzadziej można znaleźć personifikację miłosierdzia (misericordia) przedstawianego jako królowa na tronie w bardzo bogatej szacie, z koroną na głowie i nimbem. Przykładem takiej sztuki może być pokrywa chrzcielnicy w katedrze w Hildesheim ${ }^{54}$.

Na osobną uwagę zasługuje obrazJezusa miłosiernego z podpisem ,Jezu, ufam Tobie", który św. Faustyna poleciła namalować na wyraźne życzenie Jezusa z wizji w Płocku 22 lutego 1931 roku $^{55}$. Pierwszy obraz namalowany przez Eugeniusza Kazimirowskiego w 1934 roku znajduje się w dawnym kościele Świętej Trójcy, a dziś sanktuarium Miłosierdzia Bożego w Wilnie.Jednak bardziej znany jest wizerunek pędzla Adolfa Hyły z 1944 roku, przechowywany w krakowskich Łagiewnikach ${ }^{56}$. Warto dodać, że przez wieki czczono wizerunek Chrystusa miłosiernego z ewangelicznej sceny przed Piłatem "Ecce Homo" (J 19, 5), taki jak widzimy na siedemnastowiecznym obrazie w bocznym ołtarzu kościoła w Korzkwi ${ }^{57}$. Jeszcze częstsze były wizerunki Chrystusa w motywie Misericordia Domini, czyli stojącego w grobie i ze śladami męki, czasami w towarzystwie Bolesnej Matki, czego przykładem jest obraz z kościoła pod wezwaniem Przemienienia Pańskiego we Wróblowicach.

\section{Psychologiczne aspekty miłosierdzia}

Na koniec warto wspomnieć o dziedzinach, które pomagają teologii w jej refleksji nad miłosierdziem. Oczywiście głównie filozofowie zasta-

54 Por. K. S. Frank, Barmherzigkeit. VI. Ikonographisch, [w:] Lexikon für Theologie und Kirche, t. II, Freiburg i. Br. 2006, k. 17; por. C. Schweicher, Barmherzigkeit, Werke der, [w:] Lexikon der christlichen Ikonographie, t. 1, Freiburg i. Br. 1994, k. 245-251.

55 Por. J. Zabielski, Wydobywanie dobra..., dz. cyt., s. 166n.

56 Por. A. Witko, Obraz Bożego Miłosierdzia, Kraków 2004.

57 Por. Parafia Narodzenia św. Jana Chrzciciela w Korzkwi, red. Z. Płachta, s. 19. 
nawiają się nad jego znaczeniem ${ }^{58}$, ale również psychologia swoim specyficznym językiem próbuje opisać procesy, które towarzyszą doznawaniu i okazywaniu miłosierdzia. Wychodzi od dynamicznego charakteru osobowości, który wynika z wrodzonego człowiekowi pędu do rozwoju. Ta wewnętrzna tendencja jest bardziej odczuwana w momentach, w których człowiek zaniedbuje jej realizację. Jawi się wtedy w postaci kryzysu psychologicznego. Rozwój dokonuje się dzięki własnemu wysiłkowi, ale i z pomocą innych, zwłaszcza wspólnoty, do której się należy. W tym kontekście dojrzała postawa pełna miłosierdzia dla drugiego człowieka jest uwarunkowana odpowiedzialnym przeżywaniem własnej słabości i gotowością do bycia przedmiotem miłosierdzia. Jednym z terenów, na którym każdy ma prawo oczekiwać miłosiernej miłości, jest pomoc w rozwoju własnej osobowości ${ }^{59}$. Interesującą formą nawiązania relacji między psychologią a teologią, głównie teologią duchowości, są próby porównania kryzysowej sytuacji dezintegracji pozytywnej opisanej przez Kazimierza Dąbrowskiego z nocą ducha analizowaną przez św. Jana od Krzyża ${ }^{60}$.

\section{Zakończenie}

Powyższe analizy miłosierdzia jako terminu teologicznego pokazują wyraźnie, jak głęboko zakorzenił się on w tradycji poszczególnych dyscyplin. Wprawdzie miłosierdzie jest pojęciem ogólnoludzkim i występuje we wszystkich kulturach, ale dla chrześcijańskiego ujęcia znajduje źródło głównie w Piśmie Świętym. Biblia ukazuje Boga jako miłosiernego i stawia przed człowiekiem wymaganie miłosierdzia. To rozróżnienie stanowi podstawę omawiania miłosierdzia z różnej perspektywy w teologii dogmatycznej i moralnej. Dogmatyka ukazuje miłosierdzie jako największy przymiot Boga, który dzięki zbawczemu wydarzeniu Jezusa nabrał charakteru chrystologicznego. Ponieważ z Chrystusem nieodłącznie

58 Por. J. Tischner, Drogi i bezdroża miłosierdzia, Kraków 1999.

59 Por. Z. Płużek, Miłosierdzie w postawie ludzkiej w interpretacji psychologicznej, [w:] Miłosierdzie w postawie ludzkiej, dz. cyt., s. 249-254.

60 Por. J. Skawroń, Noc ducha i dezintegracja pozytywna, Kraków 2007. 
związana jest Matka Miłosierdzia, refleksja nad tym przymiotem odbywa się też w kontekście mariologicznym. Nie są od niej wolne również eklezjologia, sakramentologia i eschatologia. Z kolei teologia moralna interesuje się miłosierdziem głównie w relacjach międzyludzkich, ukazując je jako cnotę i powinność wykraczającą daleko poza same tylko uczynki miłosierne. Współczesną refleksję nad miłosierdziem charakteryzuje pogłębienie personalistycznego wymiaru więzi miłosierdzia z miłością. Zaangażowanie chrześcijan w posługę miłosierdzia poza wymiarem indywidualnym przyjmuje także postać szerszej działalności, badanej głównie w ramach katolickiej nauki społecznej. Spośród nauk teologicznych duchowość chrześcijańska wydaje się najbardziej integrować wszystkie istotne momenty miłosierdzia, od adekwatnej odpowiedzi na łaskę Bożego miłosierdzia aż po miłosierną posługę bliźnim, co łącznie stanowi istotne kryterium dążenia do doskonałości i świętości chrześcijańskiej. Wraz z rozwojem kultu Bożego miłosierdzia dostrzeżono też potrzebę refleksji natury pastoralnej, widząc w idei miłosierdzia istotną treść nowej ewangelizacji, która będąc lekarstwem na współczesne duchowe zagubienie człowieka, winna znaleźć wyraz w duszpasterstwie, szczególnie w wymiarze homiletycznym i katechetycznym. Jak widzieliśmy, prawda o miłosierdziu Bożym i ludzkim ma swoje miejsce również w liturgice, prawie kościelnym i sztuce chrześcijańskiej. Wiele uwagi poświęcają jej też dziedziny humanistyczne związane z teologią, takie jak filozofia i psychologia. Ten rozkwit refleksji nad miłosierdziem nie jest przypadkowy i płynie z niemal instynktownej potrzeby szukania głębszego sensu ludzkiej egzystencji. Im bardziej świat będzie negował istnienie grzechu i winy oraz starał się układać relacje międzyludzkie na fundamencie egoizmu lub co najwyżej ścisłej sprawiedliwości, tym bardziej człowiek będzie tęsknił za miłosierdziem i tym bardziej aktualne będą wciąż nowe próby refleksji nad jego istotą. 


\section{Summary}

\section{Mercy as a theological term}

The author of the article analyses different meanings of the term 'mercy'. He begins with the ancient use of the word by pagan philosophers. This is the background for the analysis of the term 'mercy' in the Old and New Testament. The biblical sources lead to the definition of dogmatic foundations of God's Mercy and allow the ethical and moral aspects of the human mercy to be shown. Closely connected with the last is the social dimension of the mercy. The author also deals with other dimensions of the mercy, such as: pastoral, liturgical, psychological and juridical. He also discusses the meaning of the mercy in the spirituality and Christian art.

Keywords: Divine Mercy, spirituality, Old Testament, New Testament

\section{Miłosierdzie jako termin teologiczny}

Autor artykułu analizuje różne znaczenia terminu „miłosierdzie”. Rozpoczyna od starożytnego użycia tego słowa przez filozofów pogańskich. To stanowi tło analizy terminu w Starym i Nowym Testamencie. Biblijne źródła prowadzą do dogmatycznych podstaw Bożego Miłosierdzia i pozwalają ukazać etyczne i moralne aspekty ludzkiego miłosierdzia. Z ostatnim ściśle związany jest społeczny wymiar miłosierdzia oraz jego pastoralny, liturgiczny, psychologiczny i prawny aspekt. Autor omawia także znaczenie miłosierdzia w duchowości i sztuce chrześcijańskiej.

Słowa kluczowe: Boże miłosierdzie, duchowość, Stary Testament, Nowy Testament

\section{Bibliografia}

Benedykt XVI, Encyklika Caritas in veritate.

Benedykt XVI, Encyklika Deus caritas est.

Bóg bogaty w miłosierdzie, red. L. Balter, Poznań 2003.

Hałas S., Biblijne słownictwo miłości i miłosierdzia na zderzeniu kultur, Kraków 2011.

Drzyżdżyk S., Haberka S., Nadzieja czy apokatastaza? Refleksje nad eschatologia Wacława Hryniewicza, „Polonia Sacra” 14 (32) 201026 (70), s. 127-143.

Machniak J., Doświadczenie Boga w tajemnicy Jego miłosierdzia u bł. Siostry Faustyny Kowalskiej, Kraków 1998.

Miłosierdzie w postawie ludzkiej, red. W. Słomka, Lublin 1989 (Homo Meditans, 5).

Scheeben M. J., Handbuch der Katholischen Dogmatik, t. IV, Freiburg 1948.

Seremak W., Miłosierdzie Boże a nowa ewangelizacja. Znaki czasu, Lublin 2001.

Skawroń J., Noc ducha i dezintegracja pozytywna, Kraków 2007. 
Tischner J., Drogi i bezdroża miłosierdzia, Kraków 1999.

Ukleja R., Miłosierdzie Boże z pokolenia na pokolenie, Wrocław 1997.

Warchoł P., Miłosierny Bóg i miłosierny człowiek. Teologiczna interpretacja miłosierdzia w nauczaniu Jana Pawła II, Wrocław 2007.

Witko A., Obraz Bożego Miłosierdzia, Kraków 2004.

Zabielski J., Wydobywanie dobra. Teologia chrześcijańskiego miłosierdzia, Białystok 2006. 